\title{
Grand Ideas or Delusions of Grandeur? Placing big thinkers and essential theories in property economics research
}

\begin{tabular}{|r|l|}
\hline Journal: & Journal of Property Investment \& Finance \\
\hline Manuscript ID & JPIF-11-2021-0097 \\
\hline Manuscript Type: & Real Estate Insights \\
\hline Keywords: & $\begin{array}{l}\text { Property economics, Property theory, Property methodology, Property } \\
\text { research, Property markets, Property philosophy }\end{array}$ \\
\hline
\end{tabular}

\section{SCHOLARONE \\ Manuscripts}




\title{
Grand Ideas or Delusions of Grandeur? Placing big thinkers and essential theories in property economics research
}

\author{
[Anon]
}

\begin{abstract}
Purpose - This article is looking to reflect on the various important touchstones of 'grand theory' and 'big thinkers' that can be framed when engaging empirical evidence in property economics research

Design/methodology/approach - The paper is reflexive in nature, using experiential reflection to consider theory in property economics. The importance of "methodology" is emphasised rather than "method".
\end{abstract}

Findings - Using reflexive mode, the paper does not have "findings" as such: if the views expressed are accepted, then a research agenda to better understand property economics research is implied.

Research limitations/implications - The nature of reflection is that it follows from the writer's experiential processes and interpretations. The reader may come from a different stance. Broadly accepting the propositions, there is a call for property economics research to be formulated in reason and logic, particularly as humans do not reason from facts alone. Such reasoned thinking could for example be in the property economic concepts of space and place, contracts and justice, capital and financializaton.

Practical implications -To engage with such theory would provide some depth of philosophical roots for property as a discipline. Elevating property as a 'real world' discipline rather than simply an applied mathematics discipline.

Social implications - The paper enables an understanding of how property economics research can benefit from more ontology and more inductive reasoning.

Originality/value - The paper reflects the views and experience of the author based on over 15 years of research into property economics.

Keywords Property economics, Property theory, Property methodology, Property research 


\section{Introduction}

This article reflects on various important touchstones of 'grand theory' and 'big thinkers' that can be used to frame empirical evidence in property economics research. I look to highlight writers that have focused on certain (neo)classical economic principles, and others that have shifted paradigms to bring new ways of looking at the theory of property economics. Here we focus on grand theory themes of institutions and behaviours, space and place, contracts and justice; as well as capital, financializaton, and inequality. Big thinkers contributing to grand ideas are put forward to frame and contextualise property economics, and potentially sub-fields of finance and investment into the next 40 years. Alternatively, this call to 'think big' may be more intellectual navel gazing, and thus be more a delusion of grandeur. At its heart though, this piece seeks to draw on some mainstream grand theory, to place property economics research as a discipline that can claim deeper philosophical roots.

\section{Property Economics Research in the (Neo)classical Tradition}

To begin to broaden this property economics research theory, the work by David Ricardo on the Principles of Political Economy and Taxation (Ricardo, 1817) use economic concepts such as rents (and profits, and wages) that are applied to theories of land capacity. At the forefront of Ricardo's thinking was a conclusion that land rent (the reward for owning land) grows as population increases. For John Stuart Mill, his work on the principles of political economy (1848) developed economic thinking beyond Adam Smith on markets and the wealth of nations (Smith, 1776). Mill condensed key micro-economic and macro-economic theories whilst contributing more refined and advanced ideas on property economics. The abolition of inheritance tax and the development of a cooperative wage system were two significant property related leanings towards the end of Mill's writing.

Work by Karl Marx can certainly be grouped with the classical economists when considering theory in property economics. Ownership of the means of production as class tension is particularly pertinent, especially given the relation between labour and capital. In Marx et al's (1889) critical analysis of capitalist production we see a heavy critique of capitalism from a perspective of the production process. The issue of land in critical analysis is in the works by George and the Georgist tradition, where in looking at progress and poverty (1882) we see why poverty exists against vast wealth. Here George explores interesting fiscal approaches such as land taxation.

Marshall in his principles of economics (1890) provides along running neoclassical approach that heavily concerns itself with the mathematical-diagrams of supply and demand, marginal utilities, and relative changes as elasticities. All of which have continued application to property economics research. The long-running textbook by Samuelson (1948) brought further resurgence in the field of classical economics that has application to property economics. Particularly by popularising Keynes (1936) work 
on aggregate demand in the general theory of employment, interest and money. Given the value of place and resources in property, New Keynesian economics as considered by Mankiw (2007) is of further note.

As part of the neoclassical writers on welfare economics, Arthur Pigou (1920) developed the concept of externalities which applies to property economics research. Externalities are those benefits gained or costs incurred by an external third party in a market transaction such as property. In order to deal with externalities Pigou believed that taxes could provide a disincentive to negative externality (or internalise the cost of) problems. Or that subsidies could provide an incentive to provide (or internalise the cost of providing) positive externalities for the wider society external to the market. The use of taxes or subsidies with regards to dealing with externalities is still referred to in economic circles as Pigovian taxes and subsidies.

\section{Property Economics Research in Institutions and Behaviours}

For the institutional turn in the economics of property, the work of Veblen on the theory of the leisure class (1899) began to lead the way on institutionalist thinking. The idea that economics can be dynamic rather than static given the fluidity of institutional power and change. A further core writer on institutional economics being Galbraith and his work on 'The Affluent Society' (1958). Here we see a demonstration of the growing significance of wealth in the private sector relative to the public sector. So having significant institutional economic power to effect economic outcomes in property.

Moving more into 'new' institutional economics are public choice economists such as Ronald Coase in the 1960s. Coase would begin to demonstrate that behaviours and actions outside of the invisible hand of the market, and outside of the incentives of tax and subsidy, could affect economic activity. Of particular significance was that integration of legal considerations will affect the decision to carry out a particular economic activity, such as bargaining over land due to legal costs between parties may generate different transaction costs irrespective of what the open market value suggests (Coase, 1960).

In the new institutional economic subdiscipline, Williamson demonstrates that internal economics of organisations are important to the outcomes of markets and associated hierarchies (1975). In terms of governance and policy, Ostrom's work on 'Governing the commons' (1990) more normatively stresses that the commons are less of a tragedy and more a point of collective call to action, if institutions and their evolution are put upfront in the economic analysis. As such, the work challenges the notion that common property will fail due to monopolistic tendencies. Eggertsson (2005) raises further institutionalist thought that institutions themselves are imperfect with some possibilities and limitations for reform. The strength and depth of this field of can be seen in Furubotn et al's (2005) text on the contribution of new institutional economics to economic theory. 
Behavioural economics work also has taken the property economics field into more heterodox directions, and thus new directions and implications for property. Shiller's (2000) work on irrational exuberance has argued early on that markets are driven by psychological and social factors rather than fundamental values. Especially in later editions that consider housing market bubbles. Thaler and Ganser (2015) in 'Misbehaving' gather behavioural examples in a popular format. Plus Kahneman (2011) in the popular economic-psychology book 'Thinking, fast and slow' takes economics into psychology territory, largely by distinguishing between instinct and thought in making economic decisions. Economic decision making both individually and collectively is certainly a core aspect of property, and this consideration to the field of institutional economics and behavioural economics is paramount.

\section{Property Economics Research in Space and Place}

Ideas of place in the economics property cannot escape the concepts of space and spatial considerations held with economic geography. Space as a concept can be thought of in many ways, and physical natural and social constructions space are deep rooted in the realm of philosophy. For Kant, (1781) in his 'Critique of pure reason' he sees that the experience of space can provide additional rational causal depth to what may be merely observed in empiricism. In dong so, space can employ economic concepts to understand property in relation to space.

However simple, Burgess' monocentric concentric zone model (Burgess, 1925) still plays a part in the spatial visualisation of property in concentric rings. To add economics to land, Alonso (1964) took the monocentric model and added economic rents to the various property classifications to gain greater understanding of maximum bid-rents at various distance from the core. To note, Alonso's work was inspired by von Thunen, whose Isolated State (1826) work used this model to demonstrate methods of maximizing agricultural production in concentric zones. Other spatial models of property economics significance include Hoyt's (1939) radial sector model that demonstrates spatial patterns in urban development around ribbon transport corridor development. Further foundations in spatial modelling include the multiple nuclei model as developed by Harris and Ullman (1945) to explain a spatial patchwork of different land uses.

Economic geography of property has several key writers of a more Marxian view on labour-capital relations and its governance. Harvey's 'The limits to capital' (1982) places more contemporary light on the extent of effects from capital accumulation over space. Plus, work by Massey (1995) focuses on the spatial divisions of labour and the geography of production as set by particular social structures of the time. In essence, unpacking why spatial inequalities persist via the production process. On a similar critical analysis, Smith's (1996) gentrification work almost personalises the process of gentrification in cities, seeing some form of revenge by capital on (non-capital owning) 
residents as they are displaced. The shaping and governance of capital-labour markets are also important over space. On a global scale, we see Peck's (2010) constructions of neoliberal reason putting a compelling historical critique of the neoliberal project of free(er) markets that has dominated contemporary thinking and practice. In addition to Brenner (2004), who's new state spaces explores how globalisation of capital has created new governance of the state beyond the nation.

More theoretically on the geographies of space we can make some leap of connection to property economics. Given the nature of property considered here as real property, Lefebvre and Nicholson-Smith's (1991) work on the production of space, bridging philosophy of mind and material, enabling an intellectual and practical take on how space is produced. Further though, the concept of space as both real in physics and imagined in social production, can also be applied to the economic as commodification in the economics of property. Soja (1996) in 'Thirdspace' develops real and imagined dimensions of space are used to build a new theoretical frame. In doing so, there is an important rebalancing of historical, spatial, and social considerations in the production of space.

More pragmatic applications of space to property economics are those that root themselves in 'real world' spatial phenomenon. Dicken's work (1986) in 'Global Shift' is a major textbook on globalisation of the economy in the social sciences, and this able to contextualise property economics in space. Thrift (1996) takes the spatial formation as interactions between the place, people, place and 'things'. In Sassen's (2001) global city work we find one of the first texts to crystallise thinking of city economies working as hierarchies in a global system. To make further spatial dissection, the important centre-periphery spatial differentials are raise by Garreau (1992) in 'Edge Cities'. Here we see a popularising of the 'Edge City' term for growing development of commercial hub activity outside of the urban core.

Place-making has always intrinsically considered the importance of economics in property research. Howard's (1898) futurist vision of a To-morrow with a peaceful path to real reform, republished in 1902 as Garden Cities of Tomorrow, is the initial blueprint. It sets a visual 'real' design of place that has recognisable economic issues of scarcity of space and wants of an environmentally healthy environment. For Geddes' (1915), 'cities in evolution' we find early calls to harmonise town planning by embedding the civic in its discourse, particularly given the economic challenges in a new industrial age.

Hall's (1988) 'Cities of tomorrow' as an intellectual history of urban planning and design since 1880 covers a broad history on the planning discipline, in addition to some of the economic problems that underpin its theory and practice. More directly to planning and the economy, Jacobs (1970), explored the economy of cities. Where we see from an American tradition a contribution to urban theory on the major determinants of urban growth in the economy in the late 1960 s. 


\section{Property Economics Research in Contracts and Justice}

For writers on economics in property, as different to say real estate economics, we need to consider aspects of real property ownership in various legal forms. With property ownership legal forms such as the private, public, cooperative, individual, and collective. Political philosophies and social contracts are important therefore to contextualise how economics can sit comfortably in studies of property. Hobbes' (1651) work on 'Leviathan' performs early writing on social contract, where power is handed to an absolute sovereign in return for some form of protection.

For Locke (1690). In 'Two Treatises of Government' there is a focus on natural rights and contract theory that are thought to contribute to a more civilized society. With respect to property Locke sees that civil society was created for the protection of property as life, liberty, and estate. This protection of property, therefore serves the private (and non-political) interests of its constituent members and does not promote some good that can be realised only in community with others such as esteem. Property could therefore for Locke predate the existence of government, and thus society and economic systems can be dedicated to the protection of property.

Protection of property under a social contract is also important for economics and the economy. For Rousseau (1762), 'The Social Contract' situates itself beyond the idea of the monarchy making legislative decisions, towards a social contract where we see resources representatively allocated by the people, rather than to the people. Beyond legislation there is the issue of motivations as set within moral frameworks. For Bentham (1789), the Principles of morals and legislation are set with utilitarianism, when people are motivated by gaining more utility, satisfaction, or what was people today would perceive as 'happiness'. As such Bentham sets new legal thinking on societal motivations and intentions towards property, where greater ownership of property could be seen as driving greater pleasure or happiness.

Later, more specific property focussed work by Proudhon (1840) uncovers what is meant by property, by famously pronouncing that 'all property is theft' in considering the notion private property. The idea of ownership as also public and cooperative makes the picture less clear, despite a more Marxian view of labour-capital relations by Proudhon. Despite these differences in property, the work by Linklater (2013) in 'Owning the earth' sees individualised private ownership becoming greater as a proportion. This general observation of tenure change leads to some significant economic and societal challenges, such as providing goods and services that are fundamentally public (non-exclusive) and cooperative (in joint collective ventures). In a more contemporary text, Webster and Lawrence (2003) look at how markets and planning shapes ownership in relation to property rights. Taking an institutional analysis of cooperation approaches, this text explores how transaction costs are reduced through 
cooperation, whilst includes planning as an enabler rather than inhibitor of reducing such contractual costs.

For economics in property, the legal real property consideration of justice resonates in economics and the economy. Early writers on justice such as Paine (1797) on 'Agrarian Justice', proposed that those who possess cultivated land owe the community a ground rent, which justifies an estate tax to fund universal old-age and disability pensions. The financial mechanics of which is a fixed sum to be paid to all citizens upon reaching maturity. Rawls (1971) 'A theory of justice' is a touchstone for political theory of distributive justice, looking normatively to rebalance equality of opportunity and helping the more disadvantaged in society. Here we find some consideration of political economy and economic systems to rebalance some of the injustice. In a similar consideration of justice, the important recognition by Sen (1999) from his text 'Development as freedom', serves as a reminder that economic development needs to be set in relation to freedom and access of opportunity to redress imbalances.

\section{Property Economics Research in Capital, Financializaton, and Inequality}

Capital, financialization and inequality need attention when looking at a subset of economics in property. Enlightenment writers (1715-1789) such as Rousseau (1775) in his 'Discourse on the Origin of Inequality' sees that private property is the original source and basis of all inequality. For private property as capital there are issues for exploration as to whether private ownership capital itself contributes to inequality. The 'Age of Capital: 1848-1875' by Hobsbawm (1975) sees 1860 as the birth of capitalism in political language. Here, Hobsbawm explores a period where private enterprise is maintained in a belief of developing economic growth to spur material and moral advancement. More spiritually and culturally, the concerns by Weber (1905) in 'The protestant ethic and the spirit of capitalism' sees how religious belief set mental frameworks and motivations to suit capitalist mechanisms of progress.

Capitalist progress is therefore not necessary a linear path. Gramsci (2011) in his Prison Notebooks 1931-37 sees that systems such as forms of ownership are created in part by the cultural norms of the day, where cultural hegemony form ideologies such as capitalism (and socialism). Similarly for Foucault (1970) in 'The order of things' sees that structures and categories (taxonomies) are set within the parameters of their own historical epistemological norms such as scientific discourse, and the application of economics as a science of wealth. In doing so, we see norms being reproduced by those who hold power as knowledge. To return to Hobbes' (1651) leviathan, there is the view that 'knowledge is power'. Interestingly the phrase 'knowledge is power' scientia potentia est occurs in the 1668 Latin version of Leviathan, with Latin being part of the language of a powerful elite during this period.

With Schumpeter (1942) in 'Capitalism, Socialism, and Democracy' there is further emphasis on innovation moments in time that can lead to change. For instance, an 
argument that with respect to property as capital, there will be new innovative 'things, places, and people' that tend to create and destroy rather than revolutionise. For property economics, the factor of production as entrepreneurship is seen to eventually erode capital, as a large intellectual class makes its living by attacking the very bourgeois system of private property and freedom so necessary for the intellectual class's existence.

The contribution of financialization discourse to capital and inequality is particularly interesting to economics in property. Epstein's (2005) 'Financialization and The World Economy' opens more contemporary thinking on the increasing importance of financial markets, institutions and motives in the world economy. The costs (and benefits) of such financialization to property such as housing is brought forward by Aalbers' (2016) political economy work on 'The Financialization of Housing'. In doing so, we see the centrality of housing as a capitalist instrument in the widening of financial capital. The role of housing as a financial asset to raise debt is the focus of Mian and Sufi's (2015) 'House of debt' where they look at housing debt as part of the 2007-8 global financial crisis and subsequent economic recession. The idea of financial and economic instability has generated a renewed interest in writers such as Minksy (1986) how in 'Stabilizing an Unstable Economy' considers that markets are prone towards period of 'crisis'.

Instability of finance and capital can be found in the theatre of property. For Lizieri (2009) in 'Towers of capital' we see the interesting interdependence of finance and the property. As such we can see finance manifest in many city centres that sit the supply of commercial buildings. It is in these properties that those who manage finance are further perpetuating wealth within those buildings. Capital as wealth different from income is stressed by Stiglitz, (2012) in 'The Price of Inequality' where we see a polarising of wealth groups, and the negative economic effects of such widening disparity. What Dorling (2014) would popularise as the $1 \%$ 'superrich' who are concentrating a greater portion of the wealth. With the $1 \%$ gaining greater financial protection compared to the $99 \%$ are faced with greater austerity and economic vulnerability. A leading articulation of the issues of capital and wealth (partially as backed by property) is by Piketty (2018) in 'Capital in the twenty-first century' where we see trends in the return on capital being greater than the rate of economic growth, and thus an unequal concentrated distribution of wealth causing social and economic instability. Progressive wealth taxes being one such approach to reducing minority concentration of vast wealth.

\section{Conclusion}

So in the realm of property economics, are these theories grand ideas or merely delusions of grandeur? At best, this look at grand theory in property economics provides useful conceptual framing for empirical work in the discipline. At worst, this theoretical grandstanding will be an unnecessary obstacle to getting published (except here). The 
academic publishing game largely rewards mathematical models with an appropriate narrative and concept to 'test'. Indeed, testing is good science, but what about the art of property economics research? Property economics research can be formulated in reason and logic, particularly as humans do not reason from facts alone. Such reasoned thinking could for example be in the property economic theories of space and place, contracts and justice, capital and financializaton. To engage with such theory would provide some depth of philosophical roots for property as a discipline. Elevating property as a 'real world' discipline rather than simply an 'applied' mathematics discipline. For those that have begun to ask 'why' well before the latest number crunching machine tests it. In short, this is a call to more ontology and more inductive reasoning. Towards enlightenment and wisdom. Wouldn't that be grand. 


\section{References:}

Aalbers, M. (2016). The Financialization of Housing: A Political Economy Approach. Routledge.

Alonso, W. (1964). Location and Land Use. Toward a General Theory of Land Rent. Harvard University Press.

Bentham, J. (1789). An Introduction to the Principles of Morals and Legislation. T. Payne and Son.

Brenner, N. (2004). New State Spaces: Urban Governance and the Rescaling of Statehood. Oxford University Press.

Burgess, E.W. (1925). The Growth of the City. In The City, R.E. Parks \& E.W. Burgess, Eds. University of Chicago Press.

Coase, R.H. (1960). The Problem of Social Cost. In Classic Papers in Natural Resource Economics (pp. 87-137). Palgrave Macmillan.

Dicken, P. (1986). Global Shift: Mapping the Changing Contours of the World Economy. Sage.

Dorling, D. (2014). Inequality and the $1 \%$. Verso.

Eggertsson, T. (2005). Imperfect Institutions: Possibilities and Limits of Reform. University of Michigan Press.

Epstein, G. (2005). Financialization and the World Economy. Edward Elgar.

Foucault, M. (1970). The Order of Things. Tavistock.

Furubotn, E.G., \& Richter, R. (2005). Institutions and Economic Theory: The Contribution of the New Institutional Economics (2nd ed.). University of Michigan Press.

Galbraith, K.J. (1958). The Affluent Society. Houghton Mifflin.

Garreau, J. (1992). Edge Cities: Life on the New Frontier (1st ed.). Anchor Book.

Geddes, P. (1915). Cities in Evolution. Williams \& Norgate. 
George, H. (1882). Progress and Poverty (Vol. 142).

Gramsci, A. (2011). Prison Notebooks (Vol. 2, pp. 1931-1937). Columbia University Press.

Hall, P. (1988). Cities of Tomorrow: An Intellectual History of Urban Planning and Design Since 1880 (1st ed.). John Wiley \& Sons.

Harris, C.D., \& Ullman, E.L. (1945). The Nature of Cities. The Annals of the American Academy of Political and Social Science, 242(1), 7-17.

Harvey, D. (1982). The Limits to Capital. Verso Books.

Heinrich von Thünen, J. (1826). The Isolated State. Wirtschaft \& Finan.

Hobbes, T. (1651). Leviathan: The Matter, Forme, \& Power of a Common-Wealth Ecclesiastical and Civil. Printed for Andrew Crooke, at the Green Dragon.

Hobsbawm, E. (1975). Age of Capital: 1848-1875. Hachette.

Howard, E. (1898). To-morrow: A Peaceful Path to Real Reform. Cambridge University Press. (republished in 1902 as Garden Cities of Tomorrow).

Hoyt, H. (1939). The Structure and Growth of Residential Neighbourhoods in American Cities. Washington: Federal Housing Administration.

Jacobs, J. (1970). The Economy of Cities. Vintage.

Kahneman, D. (2011). Thinking, Fast and Slow. Palgrave Macmillan.

Kant, I. (1781). Critique of Pure Reason. Palgrave Macmillan.

Keynes, J.M. (1936). The General Theory of Employment, Interest, and Money. Springer.

Lefebvre, H., \& Nicholson-Smith, D. (1991). The Production of Space. Blackwell.

Linklater, A. (2013). Owning the Earth: The Transforming History of Land Ownership. Bloomsbury Publishing.

Lizieri, C. (2009). Towers of Capital: Office Markets \& International Financial Services. Wiley-Blackwell. 
Locke, J. (1690). Locke: Two Treatises of Government. Cambridge University Press.

Mankiw, N.G. (2007). Macroeconomics. Worth.

Marshall, A. (1890). Principles of Economics (1st ed.). Palgrave Macmillan.

Marx, K., Moore, S., Aveling, E.B., \& Engels, F. (1889). Capital [Vol. 1]: A Critical Analysis of Capitalist Production. Allen \& Unwin.

Massey, D. (1995). Spatial Divisions of Labour: Social Structures and the Geography of Production (2nd ed.). Macmillan International Higher Education.

Mian, A., \& Sufi, A. (2015). House of Debt: How They (and You) Caused the Great Recession, and How We Can Prevent It from Happening Again. University of Chicago Press.

Mill, J.S. (1848). Principles of Political Economy. Appleton.

Minksy, H. (1986). Stabilizing an Unstable Economy. McGraw-Hill Professional.

Ostrom, E. (1990). Governing the Commons: The Evolution of Institutions for Collective Action. Cambridge University Press.

Paine, T. (1797). Agrarian Justice. R. Folwell.

Peck, J. (2010). Constructions of Neoliberal Reason. Oxford University Press.

Pigou, A.C. (1920). The Economics of Welfare. Palgrave Macmillan.

Piketty, T. (2018). Capital in the Twenty-First Century. Harvard University Press.

Proudhon, P. (1840). What Is Property? An Inquiry into the Principles and Right of Government. Cosimo.

Rawls, J. (1971). A Theory of Justice. Harvard University Press.

Ricardo, D. (1817). Principles of Political Economy and Taxation. London: Pelican Books.

Rousseau, J.J. (1762). The Social Contract. 
Rousseau, J.J. (1775). Discourse on the Origin of Inequality. Hackett Publishing.

Samuelson, P.A. (1948). Economics: An Introductory Analysis; With William D. Nordhaus (Since 1985), 2009 (19th ed.). McGraw-Hill.

Sassen, S. (2001). The Global City (2nd ed.). Princeton University Press.

Schumpeter, J.A. (1942). II. Capitalism, Socialism, and Democracy. Taylor and Francis.

Sen, A. (1999). Development as Freedom. Oxford Paperbacks.

Shiller, R.J. (2000). Irrational Exuberance. Princeton University Press.

Smith, A. (1776). An Enquiry into the Nature and Cause of the Wealth of Nations.

Smith, N. (1996). The New Urban Frontier: Gentrification and the Revanchist City. Psychology Press.

Soja, E.W. (1996). Thirdspace: Expanding the Geographical Imagination. Blackwell.

Stiglitz, J. (2012). The Price of Inequality. Penguin.

Thaler, R.H., \& Ganser, L.J. (2015). Misbehaving: The Making of Behavioral Economics. WW Norton.

Thrift, N. (1989). Spatial Formations. Sage.

Veblen, T. (1899). The Theory of the Leisure Class: An Economic Study in the Evolution of Institutions. Palgrave Macmillan.

Weber, M. (1905). The Protestant Ethic and the Spirit of Capitalism. Oxford University Press.

Webster, C., \& Lawrence, W.L. (2003). Property Rights, Planning and Markets. Edward Elgar.

Williamson, O.E. (1975). Markets and Hierarchies, Analysis and Antitrust Implications: A Study in the Economics of Internal Organization. The Free Press. 


\section{Grand Ideas or Delusions of Grandeur?}

Placing big thinkers and essential theories in property economics research

Squires, G

2022-03-30

22/04/2023 - Downloaded from MASSEY RESEARCH ONLINE 